\title{
The History and Theory of The Dionysian Principle "Das Dionysische" in literature and philosophy before the classical formulations of Fr. Nietzsche
}

\section{Dionysosçu İlkenin Tarihi ve Teorisi \\ Fr. Nietzsche'nin klasik anlatımından önce edebiyat ve felsefede "Das Dionysische”}

\author{
Břetislav Horyna ${ }^{1}$ (1)
}

'(Prof., PhDr., PhD.), Slovak Academy of Sciences, Institute of Philosophy, Bratislava, Slovak Republic

ORCID: B.H. 0000-0002-6610-246X

Corresponding author/Sorumlu yazar: Břetislav Horyna

Slovak Academy of Sciences, Institute of Philosophy, Bratislava, Slovak Republic E-mail/E-posta: filohory@savba.sk

Submitted/Başvuru: 05.09.2021

Accepted/Kabul: 27.11.2021

Citation/Atıf: Horyna, Břetislav. "The History and Theory of The Dionysian Principle "Das Dionysische" in literature and philosophy before the classical formulations of $\mathrm{Fr}$. Nietzsche." Felsefe Arkivi- Archives of Philosophy, 55 (2021): 1-16.

https://doi.org/10.26650/arcp.991376

\section{ABSTRACT}

The history of the opposition of the Dionysian and Apollonian principles is longer than is usually assumed. Similarly to the many of the other contrarian figures ascribed to Nietzsche, the Apollonian-Dionysian was not of his making; its history is much older and buried under a number of different layers of interpretation. In the following work I will discuss the formal aspects and content of their development, which took place under the direct authorial influence of Pseudo-Longinus, Jacob Bernays, Friedrich Schiller, Fr. W. J. Schelling and Johan Jacob Bachofen. Still, although the discovery of a principle labelled das Dionysische doesn't represent anything exceptional, the "Birth of Tragedy" treatise was a breakthrough: it began the development of a specific form of cultural critique, of which Nietzsche was the prime representative.

Keywords: Dionysius Longinus, Sublime, Bernays, Schelling, Bachofen

Öz

Dionysosçu ve Apolloncu ilkelerin karşıtlığının tarihi, genellikle varsayıldığından daha uzundur. Nietzsche'ye yüklenen çoğu karşıt figüre benzer biçimde, ApolloncuDionysosçu yapı onun eseri değildir. Söz konusu yapının tarihi çok daha eskidir ve bir dizi farklı yorum katmanının altında saklıdır. Bu çalışmada, Dionysosçu ve Apolloncu ilkelerin Pseudo-Longinus, Jacob Bernays, Friedrich Schiller, Fr. W. J. Schelling ve Johan Jacob Bachofen'in etkisi altında gerçekleşen gelişimlerinin biçimsel yönlerini ve içeriğini tartışacağım. Bununla birlikte Dionysosçu olarak adlandırılan bir ilkenin keşfi istisnai bir şeyi temsil etmese de "Tragedy'nin Doğuşu"na ilişkin inceleme bir atılımdı: Bu eser Nietzsche'nin başlıca temsilcisi olduğu belirli bir kültürel eleştiri biçiminin gelişimini başlatmıştır.

Anahtar Kelimeler: Dionysius Longinus, Yüce, Bernays, Schelling, Bachofen 


\section{Introduction}

It is possible that the true $\iota \sigma \tau o \rho$ is the philosopher poet, able to distinguish the birth of tragedy within pre-rational Dionysian elements from the death of tragedy in the post-rational rigidity of the strain of thought that froze the $\mu \tilde{v} \theta o \varsigma$ and $\lambda o ́ \gamma o \varsigma$ into a structure, an episteme, a simple voice ringing out in the momentary present. The young philologist Nietzsche was influenced by the

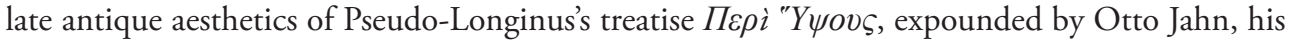
teacher in Bonn, and fascinated by the idea of destroying the individual principle (principium individuationis), which he blamed for the maladies of modern civilisation and which enticed him to stop formulating his literary and philosophical statements according to purely rational (logical) rules, but instead exclusively according to aesthetic and stylistic ones. As a result, Nietzsche wrote his first more significant but also least successful work Die Geburt der Tragödie aus dem Geiste der Musik (The Birth of Tragedy from the Spirit of Music; Nietzsche 1872; hereinafter BT) in order to announce to the world when and under what circumstances such an $\imath \sigma \tau \rho \rho$ is possible. He could not have known how many years of study and more serious publications were ahead of him before he would be mature enough to wait for Zarathustra, the philosopher of a new era and a "New Man"; that era and that person who there would be no reason to associate with novelty any more than with narration and myths, those past but still dormant cults making up the mimetic scenery of the old plays of new gods, with a hypnotic consciousness obscuring the sharp view of what is and will be present and what this new human should not merely witness with their own eyes, but also create.

These years contained a multitude of concepts and ideas, some few of which retained their strength and the ability to overwhelm a person and alter their thinking even after they had aged, and Zarathustra had joined the other gods in exile. This includes among other things the opposition of the Dionysian and Apollonian principles, calling for a reinvigorating return of the attributes characteristic of das Dionysische. Similarly, to the many of the other contrarian figures ascribed to Nietzsche, the Apollonian-Dionysian was not of his making; its history is much older and buried under a number of different layers of interpretation. Nietzsche's specific contribution is based on the transfer of the Dionysian phenomenon from the level of early Romantic poetology to a level of his own: aesthetic theory as a form socio-critical reflection and further his development of associated terminology, specifically the terms "horror" (das Grausen), "suddenness" (das Plötzliche) and "principium individuationis". In the following work I will discuss the formal aspects and content of their development, which took place under the direct authorial influence of Pseudo-Longinus (Heinecken, 1738), Jacob Bernays (Bernays, 1857), Fr. Schiller (Schiller, 1795), Fr. W. J. Schelling (Schelling, 1996; 1998) and as I believe, namely J. J. Bachofen (Bachofen, 1859). These authors represent a representative selection, not a comprehensive list. Their example can be used to show how the idea of the Dionysian-Apollonic dispute developed, especially after it spread from the Mediterranean area to Transalpine Europe. The tradition they represent is sufficiently coherent to make it possible to understand what sources and roots Nietzsche may have drawn upon without explicitly citing his sources. The focus of this study lies precisely in the explication of the Dionysian and Apollonian principles 
in literature and philosophy before Nietzsche; Nietzsche's conception itself is not currently of interest and a general knowledge of it is assumed.

\section{The last disciple of the god Dionysus}

Shortly before the commencement of his illness, Nietzsche had taken on an ever more public role of witness, initiat and disciple of the god Dionysus. But what did he mean by the phrase das Dionysische and where was the cradle of this new mythos that was establishing a religion other than the Christian Church? The answer is unclear, despite Nietzsche's relatively expansive writings on the subject; it involves some quite obvious philosophemes, mythologems taken from various sources and consequently somewhat inconsistent, the author's poetisms (from pure dithyrambs to psychologisms to some psychologically obscure formulations) and terminology, whose semiosis is partially voluntaristic (mask, surface, revelation, thyrsus, intoxication excitement, drive, fullness, fervour, wilful abandon - exuberance, enthusiasm, passion, highspirits etc.). Nietzsche's discussion of the Dionysian principle is extremely unstable, fluid and divorced from regular argumentative logic, but also productive and creative, as if it were trying to represent more than can be merely said about the Dionysian, and instead attempting to become the Dionysian representation itself.

Engaging, zealous intoxication (der Rausch) brings a feeling of growing strength and fullness; Nietzsche considered this Dionysian property significant, because it is strength and an overabundance of vitality that allow a person to escape the prison of material being (to get rid of the things surrounding us and modify them with force not only in the details, but also as to their essential forms) and having been thus liberated, form ideas and ideals. In rapture, the perception of time and space shift; everything most intimate and hidden floats to the surface, things one would otherwise not want or be able to talk about; this allows the reading in signs that are otherwise mute, enriching the internal life and altering it; and this change also increases the ability to reason, to understand and know, so that the sensory overload creates a comprehensive intelligible sensitivity, feeling becomes ripe with comprehension. This all arrives suddenly (suddenness, Plötzlichkeit is one of the central terms in the Dionysian milieu), with overwhelming strength and creating an internal pressure that entirely eliminates the effects of will.

The process of idealisation (or abstraction) built on this picture of intoxication represents the basis of all metaphysics, while presenting a key to the interpretation of art and artistic creation: for Nietzsche this was real life and the new human. It also has a reverse side: if der Rausch is missing (this exuberance of vital force is not a privilege, it is a necessity and a duty that Nietzsche thinks should guide how humans live their lives, without preconditions), what follows is emptiness, misery, unfulfillment, a hunger for life. Nietzsche only lightly sketched out the frustration of a human exposed to the void through lyrical means: in Dionysus-Dithyrambs we can read "The desert grows: woe to him in whom deserts hide...". ${ }^{1}$

1 Among Daughters of the Desert, 2 (Unter Töchtern der Wüste, 2: Die Wüste wächst: weh dem, der Wüsten birgt ... 


\section{How to instantiate something}

Nietzsche is generally acknowledged to be that instance, through which the Dionysian worldview ${ }^{2}$ invaded the tradition of European philosophy, bringing about a change in aesthetic perception, basic anthropological stances, the relationship of philosophy to myth and last but not least our understanding of the philosophy of history. He was capable of carrying out this instantiation, largely because he treated the history and theory of the Dionysian myth as a smörgåsbord: choosing elements to combine, things he considered tasteful, creating his own combinations out of borrowed knowledge and intuitions and omitting to care that one of the basic methodological rules of classical philosophy (find who copied from whom) could also be applied to him. In that case, it remains only to state: Nietzsche copied from (not only, but primarily) the following authors:

\subsection{Dionysius Longinus on the Sublime}

Nietzsche was introduced to Longinus' treaties Peri hypsos ${ }^{3}$ (De Sublimitate Libellus) by O. Jahn ${ }^{4}$, who with Fr. Ritschl was one of the most important representatives of classical German philology midway through the 19th century. Both were Nietzsche's teachers and directly influenced the formation of his philosophical and philological positions; despite the precise extent of their influence being unclear and often questioned, some of the influence is indisputable. The prime example would be the critical edition of the treaties of Dionysius Longinus by O. Jahn: in 1864-1866, Nietzsche helped work on it as a student. The treaties would have acquainted him with the theoretical and aesthetic context stemming from the term the sublime, inseparable from rhetorical pathos: a figure of speech without which the picture of das Dionysische could hardly have been painted. At the same time there was a trap here that Nietzsche failed to discover in BT: the sublime operates by subjugating consciousness and perception, exciting in them the effects of the Dionysian element: intoxication, confusion, strength, rapture, etc. Human nature rests within the strong, uncontrollable passions, in agonising relationships and pathos, through which it comes into itself. However Longinus does not lift up the effects of the sublime and of pathos, rather understanding them as a stylistic component of aesthetic expression: the sublime is an actualisation of style and is dependent on it. Longinus formulated no dichotomy of rhetorical style and effect: he was clearly aware that such a thing would be indefensible in argumentation, and it was only the budding theories of the sublime in the 18th century, incomparably more appreciative of sensitivity, emotionality and reverberations of melancholy over the logical consistency of their statements, that would throw all their chips behind the potency of the sublime.

2 Cf. DW-1, Die dionysische Weltanschauung: $\$ 1$. Abgeschlossen circa 11/08/1870.

3 The real author of the text is unknown: the earliest preserved information on the work is from the 10th century and states: "Dionysius aut Longinus" the conventionally chosen names are Longinus or Pseudo-Longinus. The actual authorship is still hotly disputed, with candidates being namely Cassius Longinus, Dionysius of Halicarnassus and several others.

4 Jahn Otto, Dionysii sive Longini de Sublimitate libellus. In usum scholarum edidit, (Bonnae: apud A. Marcum, 1867). 
In their defence, and similarly in defence of Nietzsche's somewhat unhappy retreat into flashy pathos, one could mention that while the term hypsos (sublimitas) has a long shelf-life, it is largely void of history: it has no significant historical role in the extant ancient literary before the 1st century BC, apart from several surviving fragmentary rhetorical and literary references by the Greek rhetorician Kaikillios from the Sicilian town of Calacte (Lat. Caecilius of Calacte), who lived during the reign of Augustus. This makes it conversely somewhat easier to discover what the term didn't mean, than what it was positively understood to represent in semantics and content. The text Peri hypsos makes it clear that the sublime is not the result of artistic creation (or imitation of reality), but is instead naturally itself, irreducible to rhetorical techniques, tools or styles, because it lacks "artificiality". If we were able to lift the curse from our values system, the sublime would point outside of it, to those exceptional (or "divine") thoughts we can have, but also to whatever is outside of us physically: both our ability to shape natural phenomena as well as works of art, and how this is energised with each of our new and innovative ways of seeing.

Longinus doesn't try to define the sublime, but instead (alongside his apparently contextually necessary rhetorical emphasis) considers the multifaceted nature of the sublime that the human mind reaches to when meaning is missing. The sublime has no other goal outside itself, it is a self-driven purpose that can guide the human mind. This, if it wanders, aimlessly, it will search out "that, which is truly sublime, which leads to many profound thoughts we would otherwise scarcely achieve, if at all, and which remains lodged in our memories, only painstakingly forgotten". The sublime acts with the force of lightning, suddenly, powerfully, as a beam of light in which all that is new is born. ${ }^{6}$ These musings may have been useful to Nietzsche, because they allowed him to create the basic element of his version of the cultural concept of Dionysus: If Longinus had left hypsos to antiquity as mere ancient rhetoric, then by the same principle it could be brought into the modern age as a component of modernity (and the changes it was undergoing). It is possible, but not necessary to belong in a certain world and nowhere else. The fact that Longinus' world is antiquated and "pagan" is a positive for Nietzsche; this provides him with an aesthetic aspect that is latently modern and non-Christian, free of any association with the rules, morals or singular salvation history of Christian life. Because the author of Peri hypsos clearly had no inkling of this, Nietzsche was able to defend his supposition that this is the view of the sublime held by the oldest, most originally and internally powerful impulses of antiquity, which birthed Greek mythology as well as the first gods, including Dionysus.

\subsection{The tragic thinking of Jacob Bernays}

The comprehensive works of the classical German philologist J. Bernays include an attempt to reassemble the fragments of Aristotle's Poetics. ${ }^{7}$ Although it wasn't his explicit goal, in this piece Bernays managed to elucidate Aristotle's theory of the influence and effects of tragedy,

5 Jahn Otto, Dionysii sive Longini de Sublimitate libellus. In usum scholarum edidit, (Bonnae: apud A. Marcum, 1867), p. 53

6 Ibid., p. 9.

7 Jacob Bernays, Grundzüge der verlorenen Abhandlung des Aristoteles über die Wirkung der Tragödie, (Breslau: Verlag E. Trewendt, 1857). 
the hypothesis of tragic effects that captivated Nietzsche so much so that he adopted it into the $B T$. Bernays was a student of Fr. Ritschl and bore some of the mark of Jahn's teaching, and even returned to Bonn himself as a professor after certain life events, adding to the general atmosphere the young Nietzsche grew up in.

Bernays linked the tragic effect with Aristotle's concept of кá $\theta \alpha \rho \sigma ı$ (cleansing, purging), making that the central term of the whole treatise. While Longinus' "suddenness", a violent lightning strike creating moments of inversion, is worded in anti-Aristotelian terms (catharsis should instead dampen the effects of hypnos and stand diametrically opposed to it), the following element of the contrarian image of Apollonian-Dionysian culture was introduced from Aristotle, despite being influenced by Bernays' animated disagreement with Lessing's interpretation of the Aristotelian Cathartic effects of tragedy. Bernays' starting point is in Milton and Herder and the

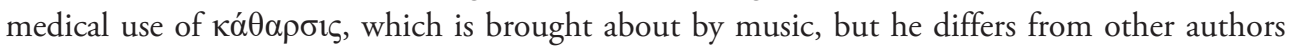
in emphasizing the possible pathological effects of tragedy. For Lessing, the cathartic effect was primarily moral, for Goethe (who also has a place in these discussions) it was conversely aesthetic. Bernays, as a classical philologist, made a brave attempt to forge his own path between both of these extremes, distinguishing himself clearly and distinctly from Lessing's distinguished interpretation ${ }^{8}$, supported as it was by translations of Aristotle's terminology.

Lessing posited that the contemporary understanding of Aristotle's concepts in Poetics

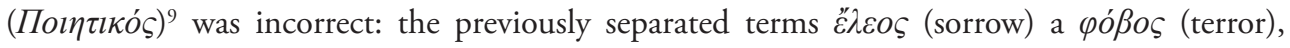
which tend to be translated pity and fear, should be interpreted together as meaning that pity leads to fear, while fear evokes pity. From this mutual interaction of pity and fear he then derived the classical Enlightenment maxim on catharsis: the audience member watching the protagonists' drama should sympathise with them, and this brings out the desirable virtues - by sympathising one becomes a moral person and this moral ablution (catharsis) from the passions relies on sympathy and fear. ${ }^{10}$ In this way, Lessing was repeatedly confirming a notion the Cartesian Pierre Corneille had been advocating for quite some time. However Bernays saw this as nothing more than (in his own words) "moral disciplinarians" and "a rival offshoot of the Church"11; a conclusion which Aristotle scarcely intended with his idea of catharsis. According to Bernays, Lessing's erroneous position was already disproven by Goethe, who, primarily in his 1827 correspondence with Riemer, thought that Aristotle considered the cathartic effect of tragedy to be the mutual balancing (harmony, unification) of the two core passions: pity and fear. Together with Goethe, Bernays took the position that catharsis meant the reconciliation of both passions, as is required by each play and consequently each poetic work. Any tragedy cobbled together from sad and terrifying events would evoke in each viewer - naturally inclined to tragic actions - the bursting forth of both emotions.

8 Gotthold E. Lessing, Hamburgische Dramaturgie, Bde. I-II, (Hamburg und Bremen: Cramer, 1767-1769).

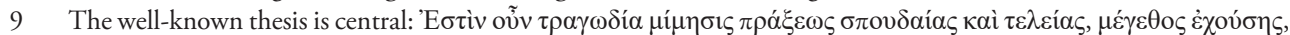

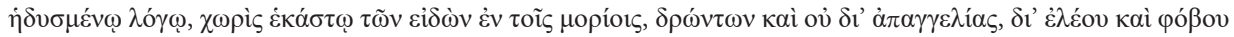

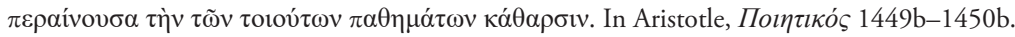

10 Gotthold E. Lessing, Hamburgische Dramaturgie, St. 74-78.

11 Jacob Bernays, Grundzüge der verlorenen Abhandlung des Aristoteles über die Wirkung der Tragödie, 136-140. 
This view of the cathartic effects of tragedy is neither moralising nor hedonistic; Bernays considered it to be the "pathological viewpoint", ${ }^{12}$ in other words exactly the thing that makes up the first typically Greek experience of rising passions and ecstasy, which the philosopher derives in order to deal with all the subsequent results of tragic thinking associated with catharsis. Tragedy relieves stress and siphons away the pressure of our emotions in the impassioned (i.e. pathologically afflicted) mind by stoking both pity and fear and consolidating them. Bernays and later also Nietzsche then describe catharsis as an action similar to a course of medical treatment: a cleansing of the ecstatic and enraptured mind from its passions is "so to speak" a cleansing of the body from pathological elements that takes place with orgiastic release (in mysteries as well as poetry and song). In this way, אá $\theta \alpha \rho \sigma ı \varsigma$ is just a specific type of $i \alpha \tau \rho \varepsilon \imath \dot{\alpha}$, using orgiastic discharge to calm the mind of the ecstatic subject, just as the removal of a toxin from the body brings back its internal balance. However ecstatic catharsis has only a temporary effect, it does not last and must be repeated: each time accompanied by feelings of ecstasy.

J. Bernays' book rapidly sparked a heated discussion: delirium, ecstasy, loss of reason, orgiastic gyrating to wild chants, the sacred rhapsodies of the Corybants, none of this could be ignored by a Germany under Kaiser Wilhelm, despite its relative liberalism. Initially, Nietzsche did not enter this debate and while he did publish his own contribution in 1872, he eventually declared it to be a collection of youthful follies (having aged rapidly) 14 years later.

\subsection{Schelling}

Sensuality, pushed to the very limits of our endurance, as is represented by the term der Rausch, makes up the basic criterion of distinction between the Dionysian and Apollonian principles, as Nietzsche noted in three consecutive aphorisms in Götzen-Dämmerung (GD Streifzüge 8, $9,10)$. He was not the first to make the link between the Dionysian principle and sensuality at its peak intensity; he was pointed towards both the term differentiation (Scheidung) as well as the concept of sensuality at the border of the distinction between the Apollonian and the Dionysian, by Schelling. Him we can thank for the philosophical basis and form of the whole Dionysian contemplation. How intimately Nietzsche was acquainted with Schelling's philosophy of mythology has been a topic of discussion, ever since it became clear how important Schelling's concept was to the Nietzschean vision of the upcoming arrival of the Dionysian element into literature, poetry and philosophy. This is largely an academic debate, because however in-depth one studies Schelling's work, it remains a matter of fact that the initial conceptualisation of the philosophy of the Dionysian myth is Schelling's and this is significantly reflected in Nietzsche's work.

Schelling wrote his first tracts on the myth as an eighteen-year-old student in Tübingen ${ }^{13}$; his last shortly before his death when elaborating on the concept of "the philosophy of mythology".

12 Ibid, 141.

13 Friedrich Wilhelm J. Schelling, Ueber Mythen, historische Sagen und Philosopheme der ältesten Welt, in: Memorabilien. Eine philosophisch-theologische Zeitschrift der Geschichte und Philosophie der Religionen, dem Bibelstudium und der morgenländischen Litteratur. (Tübingen:1793). 
He was the first to succeed in systematising the relationship between philosophy and mythology: from the initial rationalistic grasp of myth, through defining myth within the historical and rationalistic theory of myths and interpreting the myths and mythologies of ancient cultures, then introducing myth into the concept of "world ages" (die Weltalter, from its first conceptualisation in 1811 to the Munich lecture programme System der Weltalter von 1827/28), up until the philosophy of mythology itself. Here it is it is at last also appropriate to point out the concept of so-called new mythology, ${ }^{14}$ which is the systematic elaboration of the agonistic position of the Apollonian and Dionysian principles and the merging of mythology and revelation into "philosophical religion". An adequate understanding of the philosophy of mythology requires us to remember Schelling's methodology, which he formulated in the introductory text to his Berlin lectures Philosophische Einleitung in die Philosophie der Mythologie oder Darstellung der reinrationalen Philosophie (Schelling, 1846). Following up on the structure of The Ages of the World, Schelling placed his negative philosophy, which essentially restricts itself to the ontological argument, alongside positive philosophy, whose goal is to eliminate the flaws stemming from the purely logical, a priori argumentative approach of negative philosophy along the path of historical knowledge. The goal is to include historical depictions of religious items within philosophy, namely those of God (gods, deities), as conscious subjects. In this way, Schelling took a methodologically broader approach to the concept of mythology. Negative philosophy is not abandoned, but gains as a new function the logical justification of the historically-based philosophy of mythology (and subsequently also the philosophy of Revelation). The integration of both methods takes places while simultaneously confirming their individual purposes: the purpose of negative philosophy being to find and justify the first principle of being and thought using logic, with positive philosophy aiming to do the same through historical and practical knowledge. In relation to mythology, this relies on an interpretation of myth as the sediment underlying the lived religious experience. ${ }^{15}$

Within systems of German idealism, this surpasses the radical tendency to acknowledge only rational principles (Hegel), which Schelling rejected, referring to it as reinrationale Philosophie, a form of historical research into everything that is theoretically possible as a result of pure reason, and which therefore represents something historically viable.

Among other things, this opened the door to an investigation of myths and mythologies as well as their several culturally-constituted parts, including also the opposition between the Dionysian and Apollonian principles. Schelling was searching for (also taking into account his contemporaries, namely Fr. Schlegel and Novalis) a mythology of reason, in other words a didactically structured poetry, which could become part of philosophy and place itself "in service of thought". This was a comprehensive educational project where mythology becomes

14 Schelling was very likely the author of the anonymous and innovative text Das älteste Systemprogramm des deutschen Idealismus (The Oldest Systematic Program of German Idealism), which stood at the roots of the Early German Romantic concept of "new mythology".

15 Schelling presupposes the "religious experience" as fact. He does not investigate the question of what makes an "experience" religious or non-religious. 
one with poetry, which is united with philosophy and that with science, all these linked together by a general aesthetic context, complemented and completed by the religious dimension. The mythology of reason, presented in the project The Ages of the World in 1811, further develops the identity of mythology and poetry, introducing a new element of das Urlebendige (the primordial living moment), whose concealment in myth is to be uncovered by the method of reflexive dialectics. From this moment on, Schelling only acknowledges the religious dimension of mythology when the discovery of its subject fully contains its historical dimension. Since his academic lecture on the Samothracian gods ${ }^{16}$, his philosophy of mythology was supported by historically evidenced facts concerning ancient religions and myths. In this way we are able to get to the original foundation of mythology and identify ever-present and historically-influential ideas that are represented in art, poetry and philosophy. This is to make the point that mythology doesn't originate in the reflexive actions of an autonomous subject, who is only in touch with the expressions of the primordial basis (das Urlebendige), while being outside of its reach. Quite the contrary, the relation between myth and subject is rational: we have no reason to mythologise reason in order to understand the myth, because mythology itself is reason-based.

What is important for the philosophy of mythology is therefore the inversion of the mythology of reason into a concept of reasoned mythology. This reversal presupposes that we distinguish between two types of myth: the historical and the philosophical, ${ }^{17}$ which is crucial since the historical myth as the subject of mythology remains a summarisation of culturally constitutive (poetic) ideals formulated in the past, while the philosophical type of myth (combined with reason and imagination) has the potential for a new mythology. Schelling also introduced his "concept of Dionysus" into the philosophy of mythology, creating a doctrine around that term, something Schelling considered the key to all Greek mythology, ${ }^{18}$ due to the possibility of finding the Dionysian element in crucial parts of the old religions that existed before Greek culture, especially in identification with Egyptian Osiris. Before Osiris, its origins stretch back even to the oldest star-worshipping cults ${ }^{19}$ (Sabaeanism), which Schelling saw as the origins of human religiosity: for Greek mythology this means that Dionysus is in essence (not however in his full

16 Friedrich Wilhelm J. Schelling, Ueber die Gottheiten von Samothrace, Beylage zu den Weltaltern. (Stuttgart Tübingen: Johann Georg Cotta von Cottendorf, 1815).

17 The work Philosophie der Kunst from 1802-1803 additionally contains an aesthetic interpretation of myth.

18 Schelling, Philosophie der Mythologie, in: Sämmtliche Werke XI.

19 Astral cults permeate not only Greek mythology, but also one of the great traditions of European mysticism, aimed at discovering the perfect, complete and total humanity of a human being equal to a god; which led to the idea of Astralis, the man from the stars, whom humans seek so that he may take their place: where people have failed, this new astral human - as understood by J. Böhme, Novalis and finally Nietzsche (der tolle Mensch, Zarathustra) should succeed. The identification of Dionysus as the essence of astral cults would explain why Nietzsche considers the name "Dionysus" the origin, the primordial hidden fountain of philosophy as well as its future, purpose and goal. According to Hebrew and Arab sources, the "festival of the full moon" associated with Sabaeanism was celebrated every $14^{\text {th }}$ day of the month as a holy day of the god of light or king of the world (the creator of the world, Ohrmazd in a Mazdaist environment) and became the source of further cults of light, but also of the moon or full moon, a common element in mythology. The Greek goddess of the moon Hekate, originally worshipped in Asia Minor, developed from a Titan into an omnipotent deity, who mythology identified with Persephone (related to Dionysus through Demeter) as well as with Isis (related to Dionysus through identification with Osiris). 
realisation) as old as Urania, ${ }^{20}$ the celestial ruler at the origins of Greek mythological astrology, ${ }^{21}$ as well as Urania's father Zeus, whose son he can only be considered when taking on one specific form. Otherwise this is still the oldest, primordial principle, whose essence rests in a continuous, but never fully completed "arrival". In his most general central position within the history of ancient Greek mythology, Dionysus is definitely an arriving god, ${ }^{22}$ who turns up (manifests) in events and finds fulfilment within them.

However, according to Schelling, Dionysus also takes special systematic place of the second god, or the god of "second potency". He becomes this after breaking out of the original (divine) unity accepted in astral cults of "primal humanity" and beginning a series of processes of actualisation, where factors such as strength, action, influence, phenomenology, movement, metamorphosis are at play; these are physical elements as opposed to mere "perception" (spiritual vision), which instead directs consciousness through immobility, permanence, original inertia - and so also into a state of bondage, an inability to escape the destiny imposed upon us. Dionysus became a materialised god and was thus accessible to humanity as something linked to the divine, while at least still having the potential for incarnation. The physical forces associated with Dionysus were also important to Schelling, because they allowed him to declare his philosophy of mythology to be a natural philosophy (SW XII, 285). At the same time he could save Dionysus from merely "lingering" in that first infinite and unchanging state of a therefore "blind" god, with the level of vitality to be expected from philosophical mythology. Meaning that despite the second potency being more than just a spiritual entity, neither is it a physical phenomenon (an object, a natural subject), but instead becomes the very potency that allows for both nature and carnality through its arrival (being perceived).

Schelling interpreted Dionysus as a type of principle that overcomes its origin, but as a result this eliminated the originality and natural value of living nature itself. Nature becomes real and living together with the coming of Dionysus's second potency, the Dionysus of transformation, ecstasy, wine and mysteries. It is however subject to his endless arrival: just as Dionysus materialises, so does (natural) life emerge in nature, an essentially unnatural image. Just like Nietzsche, Schelling also missed this association: to the contrary, Schelling even confirmed that the god who freed human consciousness from the bonds of primal immovability and stubborn inertia, injecting it with a concoction of vitality together with materiality and powerful emotions,

20 Schelling relies on Herodotus's notes (III, 8) on ancient Arabic religions, where two gods were prominent: the Greek Urania (Alilat in Arabic) and Greek Dionysus (Urotal in Arabic). Through a relatively complicated process of deduction he shows that Alilat means "mother" or "the mother of god" and that Urotal is "son of the mother". Later interpretations explain this association (also adopted from Herodotus) through the apparent fondness of Arabic tribes for creating connections, blood ties (cf. Köster 156).

21 Without distinction between astronomy and astrology (or magic), which blend together in the Greek notion of "stargazing".

22 The image of Dionysus as the "approaching god" was popularised by M. Frank (Manfred Frank, Der kommende Gott: Vorlesungen über die Neue Mythologie, (Frankfurt: Suhrkamp Verlag, 1982.)) 
could be referred to as $\Lambda v \sigma l o \varsigma^{23}$ This term should not be confused with the idea of redemption ${ }^{24}$ and redeemers; even Schelling follows up with an analogy in which Dionysus removes one's worries by giving them wine. Similarly, the human race is relieved of that "blind" real and primal god by leaving him to the past, opening life up to a plurality - meaning both the plurality of nature and natural phenomena, but also the plurality of experiences, and especially the plurality of the gods themselves. In his second potency, Dionysus becomes a fountain of polytheism, an open polytheism in harmony with nature, transforming the initial united immobility into a multifaceted movement, providing humanity with answers from many perspectives. Schelling also noticed the cultural upheaval necessarily resulting from the sudden movement of previous immobility in the reactions to the closest mythological figure to Dionysus: Demeter, who had a long and difficult time adapting to the new situation. The story of her acceptance of polytheism is known as the kidnapping of her daughter Persephone, in other words the story of a crime committed on the child of a mother goddess, who as Schelling claimed "...is the figure through which Hellenistic mythology gained all its character. The whole world of Greek gods could not have existed without Demeter". ${ }^{25}$ Schelling reads the daughter's abduction as a betrayal of the original single god, placing Demeter as a goddess abandoned by god and gods, leaving their world and entering into the human one, where the resulting grief, hunger, craving and lust for revenge and intoxication become a representation of consciousness on the edge, mediating between mythology and mystery. ${ }^{26}$ Referencing the Homeric hymns dedicated to Demeter, ${ }^{27}$ Schelling presents the situation as an offer from the goddess: if you appease my sorrow and make me forget the treason, reconcile my mind, I will give you occasion for orgies, sacred acts that draw up vitality and joy. The Eleusinian Mysteries, whose aetiology the hymn describes, are at the same time Dionysian mysteries: the god previously realised in his second potency now enters the mysteries, in triumphant processions of gay abandon, into feasts of bread (Demeter) and wine (Dionysus), climaxing with his initiation into the mysteries behind transcending the death of abandonment, damnation and immobility. Dionysus is born again, comes once again into his third potency, distinguished from the previous by a change in tension towards the primordial, blind and unmoving god. Dionysus is now all: "All" refers to the levels of consciousness realised within him, which mutually transcend each other (as can be illustrated through the image of the triple self-transcendent divine woman, the feminine element without which das Dionysische is unimaginable, Urania, Semele and Demeter) and meet once again in the theogony of the birth of Dionysus, culminating in Dionysus's complete ideal. As a whole, this is the result of Schelling's

23 "Als der Gott, der das Bewußtsein von der strengen, verzehrenden Gewalt des ersten Prinzips erlöst, heißt er auch Avølos" (Schelling 1992, 291).

24 If this does happen, it tends to be due to synonymity with the term for redemption, for example from slavery or

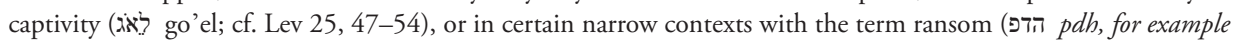
offerings, but also to buy someone from debt bondage). Schelling does not consider this overlap in terminology when conceiving his philosophy of Dionysian mythology.

25 "Demeter ist die Gestalt, durch welche die hellenische Mythologie ihre ganze Eigentümlichkeit erhält. Ohne Demeter gäbe es keine griechische Götterwelt." Cf. Schelling SW XII, p. 631.

26 Friedrich Wilhelm J. Schelling, Urfassung der Philosophie der Offenbarung I-II, hg. von Walter E. Erhardt, (Hamburg: Meiner, 1992), p. 267.

27 Hine, D. (1972), The Homeric Hymns. The Battle of the Frogs and Mice, New York: Atheneum. 
attempt to achieve a philosophy of mythological consciousness, which avoids contradiction with the premises of philosophical myth and rational mythology alike. This met with success and became an offer it was possible to grasp, adopt, disprove and reject, or move to a further level of interpretation. The latter is exactly what Nietzsche did.

\subsection{J. J. Bachofen}

Bachofen used the myth analysis method. This lead him to symbols, which the myth itself was a mere exegesis of, developing along externally differentiated but internally linked routes (mythical action) leading back to the thing represented by the unified symbol itself. According to Bachofen, myth had hidden this original and unifying symbol under a growing diversity of mythic narratives (exegeses) and mythical actions (mysterious drômen). The intuition of primordial unity faded out, and instead rationalisation imbibed myth with the ever fresh and uncertain forms of life in ancient cultures. Bachofen calculated that if he were able to use myth analysis to uncover the basic cultural ideas contained in symbols, he could attempt another description of the history of these cultures better than those before him: drawing from the transformations and fragmentary residual thoughts that once created a certain cultural state and its collective memory, was going to be safer than hermeneutical "pre-understanding" and euhemeristic descriptions of "facts" that are unknown. This understanding of history is then not concerned with events that "really happened", but rather the Zeitgeist or spirit and culture contained in tradition, including that of mythical narratives. His contemporaries already considered this to be too strong an influence of personal preference and intuition, not merely the opposition to rationalism and positivism. The investigation of the relations between people, groups and cultures on such a vague basis as "Zeitgeist" drew the ire of experts as well as support from authors expecting a return of the mythic consciousness, the remythisation of modern thought and any available ecstatic and imaginary transcendence.

J. J. Bachofen was one of Nietzsche's principle direct inspirations for his analysis of the relationship between the Apollonian and Dionysian elements in Greek mythology. In his work Versuch über die Gräbersymbolik der Alten from 1859 there are several places where Bachofen discusses the links between the gods Apollo and Dionysus. Two examples stand out the most:

Diogenes also belongs to the Moon religion. Previously we've met him on two cosmic levels, first in his unification with the telluric matter, as the carrier of virile strength in the shape of the chthonic waters and chthonic fire, and once again as a shining Sun, the heavenly phallus in Apollonian garb, who just, like the materialspawning Helios, is subservient to the metaphysically pure nature of Apollo. ${ }^{28}$

28 "Diogenes gehört auch der Mondreligion an. Wir haben ihn bisher auf zwei Stufen des Kosmos gefunden, zuerst in seiner Vereinigung mit den tellurischen Stoffen, den er als Träger der männlichen Kraft in Gestalt der chthonischen Gewässer und des chthonischen Feuers durchdringt, dann wieder als leuchtende Sonne, als himmlischen Phallus, apollinischer Natur verwandt, der als stofflich zeugender Helios der metaphysisch reinen Apollonatur untergeordnet ist.” Johann J. Bachofen, Versuch über die Gräbersymbolik der Alten, (Basel: Bahnmaiers Buchhandlung, 1859), p. 76. 
After this elementary description there follows a comparison with mythological interpretations, showing the direction Nietzsche could subsequently follow when uniting the telluric and solar potentials within Dionysus:

Now he is presented to us in his third form. Once more he returns as Lunus Deus,

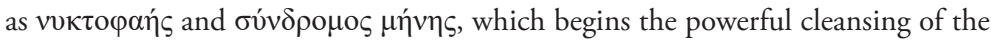
heavenly constellations. (...) In this unification of both sexes, the male may appear higher, due to its origin in the Sun, however the female predominates due to its materiality. For this reason, Luna is more common than Lunus and sometimes even the term Luna the god is used, since $\psi v \chi \eta$ is feminine, voṽ $\varsigma$ masculine, $\sigma \omega \mu \alpha$ neuter. (...) The three parts of the Dionysian being: earth, water and light, come back once more unified in the Moon. Just as it takes the place of the middle sphere connecting Earth with the Sun, so does Dionysus have equal share in the telluric and solar nature; purer than the Earth is, after all, still less pure than Apollo, the material Helios (...) Apollo will never be Lunus. He belongs to the existent world, does not take part in the forthcoming one. He is not part of its transformation. ${ }^{29}$

The Dionysian properties that Bachofen mentions, are more of a poetic than a mythical determination (Dionysus is the one who "shines into the night" and who "travels with the

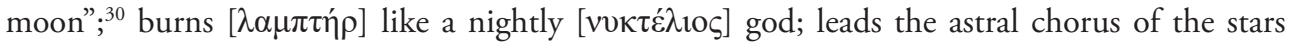

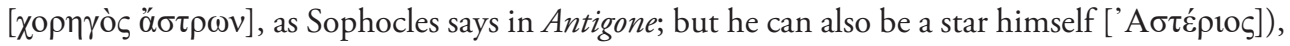
due to the aesthetic intentions of the $B T$, these were of a special importance to Nietzsche. He rallied powerful language to psychologise the Apollonian-Dionysian concept pair, using it to express a special kind of respect (stretching into the philosophy of art) for ancient Greek culture, its decadence and power, bursting forth suddenly in the most tragic moments as a dark and primordial Dionysian strength. The two antithetical states of mind that fuel the transformation of the world are based in the double-faceted complexity described by Bachofen. In himself, Dionysus represents and carries all the differences and alternate potencies, as well as real and potential harmonies: subsequently he becomes an incarnation or representation of Greek polytheism as a way of experiencing the polysemantic world of individuals, who (unlike the amorphous modernist subject) have their own characteristic properties, their own moments, some spiritual, some esoteric, others exclusively carnal.

\section{Conclusion}

At the time of writing the $B T$, Nietzsche was a young scholar, a graduate of classical philology, armed with a broad knowledge of ancient literature, well versed in Latin and apparently also

29 Johann J. Bachofen, Versuch über die Gräbersymbolik der Alten, 77-79.

30 They originated with a $5^{\text {th }}$-century Byzantine poet Nonnos of Panopolis, author of the last extensive epic poem

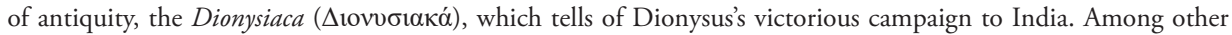
epithets it includes $\theta \eta \lambda v \mu \alpha v \eta ́ s$ (lusting for women). In general Dionysus is a god of many names; Hederich's lexicon from 1770 already mentions 75 (Benjamin Hederich, Gründliches mythologisches lexicon, (Leipzig: In Gleditschenshandlung, 1770), p. 512), with newer lists going over 100. 
Greek, with no knowledge of mathematics and no further living language. Over the past five years he had established a number of excellent starting points for his own contemporaneously innovative research, with a focus on ancient Greek pessimism (under Schopenhauer's influence) and materialism (under the analogous influence of Fr. A. Lange), nevertheless he chose a more or less conventional view of myth and tragedy. If there was anything exceptional about his take on the problem, it was the weak implementation, the gaps, the baffling lack of a concept, all of which go to show the number of individual psychological elements involved in Nietzsche's written work. Another typical thing for the author was his lack of references ${ }^{31}$ or his lifting of entire themes from sources that he sneeringly mocks (among others, early Romanticism).

Nietzsche lectured on the duplicity of the Apollonian and Dionysian principle for the first time in the summer semester of 1870 as part of his lecture on tragedy, and just by posing it as an antithesis, he was following similar aesthetic and psychological depictions as J. Winckelmann, ${ }^{32}$ as J. G. Herder, the historical and cultural interpretation of J. Creuzer ${ }^{33}$ and especially the theory of myth by K. O. Müller, ${ }^{34}$ F. G. Welcker, J. Bachofen. The poetic basis of the dithyrambic intoxication in Dionysian orgies, worshipping the principles of bread (Ceres, Demeter) and wine (Iacchus, Dionysus) was given to Nietzsche by Hölderlin, most significantly in his elegy Brod und Wein (Bread and Wine), an impression of mystery and initiation from early Romanticism (Fr. Schlegel, Novalis). From the very start, the text of the $B T$ had few claims to scientific rigour (small scope, missing notes, indexes) and subjected Nietzsche to harsh academic critique. ${ }^{35}$ The discovery of a principle labelled das Dionysische doesn't represent anything exceptional, while the attacks on ancient art (especially Euripides) were pointless, undecidable, based on mere taste and had nothing to do with either the philosophical theory of myth or the concept of Dionysus. Despite this, the $B T$ treatise was a breakthrough: it began the development of a specific form of cultural critique, of which Nietzsche was the prime representative and despite its continuation by his imitators at the start of the $20^{\text {th }}$ century (L. Klages, A. Schuler, S. George, K. Wolfskehl and others).

31 In the $B T$ especially Bernays. In a letter to E. Rohde, Nietzsche wrote that Bernays had described the $B T$ as a summary of his own opinions, albeit severely exaggerated: "Das Neueste ist daß Jacob Bernays erklärt hat, es seien seine Anschauungen, nur stark übertrieben. Ich finde das göttlich frech von diesem gebildeten und klugen Juden, zugleich aber als ein lustiges Zeichen, daß die 'Schlauen im Lande' doch bereits etwas Witterung haben." Cf. BVN-1872, 277, Brief an Erwin Rohde: 07/12/1872. It was Cosima Wagner who brought Nietzsche's attention to Bernay's reaction in her letter of 4 December 1872. Cf. Gründer, K., 1968, p. 512.

32 Johann J. Winckelmann, Geschichte der Kunst des Alterthums, (Dresden: 1764); Buch $5 \$ 11$.

33 Friedrich, G. Creuzer, Symbolik und Mythologie der alten Völker, besonders der Griechen Bd. 3, (Darmstadt - Leipzig: Carl Wilhelm Leske, 1810-1812), IV. 34, 90.

34 Karl O. Müller, Die Dorier. Vier Bücher, (Breslau: Josef War und Comp, 1824).

Karl O. Müller, Kleine deutsche Schriften über Religion, Kunst, Sprache und Literatur, Leben und Geschichte des Alterthums (vols. I-II). (Breslau: Josef War und Comp, 1848).

35 Ulrich v. Wilamowitz-Moellendorff, Zukunftsphilologie! eine Erwidrung auf Friedrich Nietzsches "Geburt der Tragödie“. (Berlin: Gebrüder Borntraeger, 1872). 
Peer-review: Externally peer-reviewed.

Conflict of Interest: The author has no conflict of interest to declare.

Grant Support: The author declared that this study has received no financial support.

Hakem Değerlendirmesi: Dış bağımsız.

Çıkar Çatışması: Yazar çıkar çatış,ması bildirmemiștir.

Finansal Destek: Yazar bu çalışma için finansal destek almadığını beyan etmiştir.

\section{References / Kaynaklar}

Bachofen, Johann J. Versuch über die Gräbersymbolik der Alten. Basel: Bahnmaiers Buchhandlung, 1859.

Beach, Edward A. Schelling's Philosophy of Mythology. New York: 1991.

Bernays, Jacob. Grundzüge der verlorenen Abhandlung des Aristoteles über die Wirkung der Tragödie. Breslau: Verlag E. Trewendt, 1857.

Creuzer, Friedrich, G. Symbolik und Mythologie der alten Völker, besonders der Griechen Bd. 3, Darmstadt Leipzig: Carl Wilhelm Leske, 1810-1812.

Frank, Manfred. Der kommende Gott: Vorlesungen über die Neue Mythologie, Frankfurt: Suhrkamp Verlag, 1982.

Gründer, Karl. “Jacob Bernays und der Streit um die Katharsis“. In Epirrhosis: Festgabe für Carl Schmitt. Hg. v. H. Barion, E.-W. Böckenförde. 495-528, Berlin: Duncker und Humblot, 1968.

Hederich, Benjamin. Gründliches mythologisches lexicon, Leipzig: In Gleditschenshandlung, 1770.

Heinecken Carl H. Dionysius Longin vom Erhabenen, griechisch und deutsch, Leipzig - Hamburg: Conrad König Verlag, 1738.

Jahn, Otto. Dionysii sive Longini de Sublimitate libellus. In usum scholarum edidit, Bonnae: apud A. Marcum, 1867.

Köster, Friedrich B. Erläuterungen der heiligen Schrift Alten und Neuen Testaments aus den Klassikern, besonders aus Homer, Kiel: Universitäts-Buchhandlung, 1833.

Lessing, Gotthold E. Hamburgische Dramaturgie. Bde. I-II, Hamburg und Bremen: Cramer, 1767-1769.

Müller, Karl O. Die Dorier. Vier Bücher, Breslau: Josef War und Comp, 1824.

Müller, Karl O. Prolegomena zu einer wissenschaftlichen Mythologie, Göttingen: Vandenhoeck und Ruprecht, 1825.

Müller, Karl O. Müller, Eduard. Kleine deutsche Schriften über Religion, Kunst, Sprache und Literatur, Leben und Geschichte des Alterthums (vols. I-II). Breslau: Josef War und Comp, 1848.

Reibnitz, Barbara von. Ein Kommentar zu Friedrich Nietzsche, "Die Geburt der Tragödie aus dem Geiste der Musik", Stuttgart: Weimar, 1992.

Schiller, Friedrich. Über das Erziehung des Menschengeschlechts in einer Reihe von Briefen, in Die Horen, 1. und 2. Stück, Tübingen: J. G. Cotta’sche Buchhandlung, 1795.

Schelling, Friedrich Wilhelm J.), Ueber Mythen, historische Sagen und Philosopheme der ältesten Welt, in: Memorabilien. Eine philosophisch-theologische Zeitschrift der Geschichte und Philosophie der Religionen, dem Bibelstudium und der morgenländischen Litteratur. Leipzig, Crusius 1791-1796, Tübingen:1793.

Schelling, Friedrich Wilhelm. J. Ueber die Gottheiten von Samothrace. Beylage zu den Weltaltern. Stuttgart Tübingen: Johann Georg Cotta von Cottendorf, 1815.

Schelling, Friedrich Wilhelm. J.: Philosophie der Mythologie: in drei Vorlesungsnachschriften; 1837/1842. ed. K. Vieweg, München: 1996.

Schelling, Friedrich Wilhelm. J. Urfassung der Philosophie der Offenbarung I-II, hg. von Walter E. Erhardt, Hamburg: Meiner, 1992. 
Schelling, Karl Friedrich A., Hg. 1958: F. W. J. von Schellings sämmtliche Werke, 1. Abteilung: 10 Bde. (= I-X); 2. Abteilung: 4 Bde. (= XI-XIV). Stuttgart/ Augsburg 1856-61. [= Schellings Werke. Nach der Originalausgabe in neuer Anordnung hg. v. M. Schröter, 6 Hauptbde, 6 Ergänzungsbde., München $\left.1927 \mathrm{ff},{ }^{2} 1958 \mathrm{ff}\right]$.

Schelling, Friedrich Wilhelm. J. Philosophie der Mythologie und reinrationale Philosophie. 1846. Philosophische Entwürfe und Tagebücher 12, XXXI, Hamburg: Meiner, 1998.

Schelling, Friedrich Wilhelm. J. System der Weltalter. Münchener Vorlesung 1827/28 in einer Nachschrift von Ernst von Lasaulx. Frankfurt a. M.:Vittorio Klostermann, 1998.

Wilamowitz-Moellendorff, Ulrich v. Zukunftsphilologie! eine Erwidrung auf Friedrich Nietzsches „Geburt der Tragödie“. Berlin: Gebrüder Borntraeger, 1872.

Wilson, John E. Schellings Mythologie. Zur Auslegung der Philosophie der Mythologie und der Offenbarung, Stuttgart Bad Cannstatt: Frommann-Holzboog, 1993.

Winckelmann, Johann J. Geschichte der Kunst des Alterthums. Dresden: 1764. 